\title{
Discussion on the value of medical baths for invalid soldiers
}

\author{
Septimus Sunderland \\ President of the Section, in the Chair
}

This article was first published by JRSM in Volume 8, March 1915. Our full back archive is available online at jrs.sagepub.com.

The President (Septimus Sunderland) stated that the Council of the Section were anxious to assist in the alleviation of the sufferings of their militant countrymen during the War. They were under the impression that many of the soldiers invalided from the Front, suffering from the effects of injuries, exposure to cold and wet, and the great nervous strain incident to military service, would receive much benefit from treatment at British health resorts.

In order to obtain some definite opinions from the Members of the Section they had arranged that this meeting should be devoted to a discussion on the subject, and hoped to be able to come to some definite decision.

\section{The value of medical baths for invalid soldiers by $\mathrm{R}$ Fortescue Fox}

The treatment of wounded and invalid soldiers by means of climate and medical baths is a matter that closely concerns the Section of Balneology and Climatology. Our Section represents in this country a branch of medicine in the study and elucidation of which it has been engaged for 20 years. But I conceive that at the present time this is a subject that, outside the limits of the Section, must appeal to our colleagues the physicians and surgeons who are devoting themselves to the treatment of military cases in our hospitals. It concerns them because it supplements their work. And we have also reason to extend our view a little further, because so large unfortunately are, and will be, the numbers of sick and wounded, that the practical issues arising out of the matter of this discussion will make their appeal to the public at large, and to those who are responsible for the public service.

The question has therefore a certain urgency, a little removed from the usual academic atmosphere of our meetings, and I gladly accede to the request of the Council to open its discussion on this the first available occasion.
In setting forth the value of medical baths for invalid soldiers, I shall rely upon a threefold argument: In the first place, historical evidence; second, the contemporary practice of other countries; and lastly and chiefly, the known facts as to the action and uses of baths which have afforded us in recent years the sure foundation of medical hydrology.

It is true that, like preventive medicine, the treatment of chronic disease is a comparatively tame affair. The after-treatment of the sick or wounded soldier presents but little opportunity for brilliant discovery or rapid results, such as the surgeon often achieves. Ours is by comparison a slow and tedious task, but if slow it is also needful. We know that after the most skilful hospital treatment for injury or illness in the field there is in many cases a prolonged period of convalescence, marked by chronic illness or disability. It is at this stage on the road to recovery that these remedial agencies, waters and baths in their various forms, and other kinds of physical treatment, will, under skilled and patient medical direction, give the best possible results. Indeed, our proposition is that without the scientific use of these agencies in the after-treatment of military cases the best results will not be obtained.

It is not surprising that upon the Continent, which has been so often ravaged by wars, this department of practice should have been studied and followed far more than in our own favoured country. And this is true not of recent times only, but from ancient days. It is interesting to notice that the greatest military Empire in history, that of Rome, fully appreciated the value and indeed the necessity of health resorts for its home and colonial populations. We have ample evidence of the fact that not only senators and officials, but the legionaries exhausted by campaigning, had recourse to the natural hot baths for periodical treatment and rest. Wherever thermal springs were found bath establishments were maintained by the government with great care throughout the Empire-in Italy, Northern Africa, Egypt, Gaul, 
Germania, Syria, and Britain. At the sites of many of these baths inscriptions are still found testifying to their medical use by the military. Indeed, for 600 years the Roman therma, munera divum, afforded one of the chief means of medical aid to all classes, both for the prevention and the cure of disease. ${ }^{1}$ Many of the Roman baths have been irretrievably lost; many were subsequently rediscovered and restored by the Mahommedans; many remain and have been in continuous use for 2000 years.

In some Continental countries, as in Italy, the employment of bath treatments for the military has been traditional almost from the Roman period. At the present time there is in many of them an organised system under government direction. The machinery, according to my information, is somewhat different in the different countries.

\section{France}

In France (1) the large military hospitals and (2) the hopitaux militarisés (that is, civil hospitals used for the reception of military patients) include, in each case, special establishments for the reception of military patients at certain selected watering-places and health resorts. These are known as hopitaux d'eaux minérales and établissements civils d'eaux minérales respectively. This branch of the military hospital service is regarded as an essential part of the organisation for the after-treatment of soldiers in France. Out of the 33 permanent French military hospitals, three are situated at health resorts-viz., that of Vichy with 212 beds, that of Barèges with 225 beds, and that of Amélie-les-Bains with 418 beds. Among the 216 hospitals, described as mixtes or militarisés are included bath hospitals at the well-known spas, Plombières, Bourbon-l'Archambault, and Bourbonne-les-Bains, as well as others at climatic resorts such as Nice, La Rochelle, Dunquerque, and Dieppe. In Algeria and Tunisia there are the military establishments of Hammam R'hira, with 50 beds, and Hammam Lif. It will be noted that some of these hospitals have been set up at the seaside as summer resorts, and that others, like those at Nice and Marseilles, have a winter season but are available throughout the year.

A few particulars of the French hopitaux thermales militarisés may be of interest.

Barèges is a mountain spa at an elevation of $4,000 \mathrm{ft}$., in the Pyrenees. The waters are thermal and sulphided, containing a glairy organic substance - "barégine" - and have enjoyed for 300 years a reputation for old gunshot and other wounds and painful cicatrices. The thermal baths, like the semi-alpine climate, are stimulating and "excitant", and are taken in vast piscines or bathingpools, in flowing water at $99^{\circ} \mathrm{F}$.
Eaux Bonnes is another of the group of sulphur spas in the Pyrenees. The old name, Eaux des Arquebusades, was given to it after the Béarnese soldiers wounded in the battle of Pavia (1525), who resorted thither to be cured. ${ }^{2}$

Bourbonne-les-Bains, in the Vosges, is a hot spring, feebly muriated and calcareous. Dr Martin tells me that it has been a resort for wounded soldiers for centuries, and the baths are considered good both for rheumatism and for wounds. The hôpital militarisé at Bourbonne has more than 300 beds, and is fitted with a modern equipment for the baths, as well as for massage, hydrotherapy and mechanotherapy.

Hammam R'hira, in Algeria, is an old Roman station, with hot calcareous waters, closely resembling in constitution and temperature a sister Roman station, the English Bath.

I have been fortunate enough to obtain some particulars of the Algerian military bath hospitals, which will be of interest to the Section. Upon the conquest of Algeria by the French in the fourth decade of last century, they found here and there some dilapidated but still massive bathing-pools or piscince of the Roman age. It occurred to the French military doctors, familiar with the historical practice in France, to use the thermal waters of Algeria for treating the sequelae of wounds, and for the anaemia and debility in the soldiers, which resulted from climate, or from fever and the fatigue of war. The engineers were accordingly directed to restore the Roman baths. The piscinae were again excavated, made good and fenced in, and at several of the ancient hot springs a kind of camp was organised where the officials and the sick lodged together in tents. The results following these simple means were so good that a few years later the military authorities decided to erect regular establishments, of which the first in date was that of Hammam Meskoutin, founded by the Médecin-inspecteur Bégin in 1843. Complete statistics of the cases treated at Hammam Meskoutin, including diagnosis and results, were kept from the beginning, and caserecords of about 2000 cases have been preserved. ${ }^{3}$

It is probable that these figures may be accepted as fairly representing the treatment of medical and surgical military cases at thermal baths. Rheumatism accounts for nearly half the total, or 904 cases, including both the civil and military, rheumatic affections being common in Algeria. Of these, 789 were cured or relieved by the baths. The next group is exclusively military, 509 cases resulting from traumatic lesion. These comprise unhealthy or adherent cicatrix, nerve pains, muscular atrophy, bony deformation, articular and peri-articular effusions - all following gunshot wounds - also fractures, 
dislocations, sprains, and other injuries. Of 283 cases resulting from gunshot wounds sub- mitted to the baths, 225 were cured or relieved; of fractures, 90 out of 101; of dislocations, 10 out of 13; of sprains, 19 out of 23. At Hammam R'hira the military bath hospital is furnished with three piscines of moving water, also with bathrooms and douches, and has accommodation for 50 officers and men.

"The action of thermal waters," says Hanriot, "especially if sulphided or chlorided, is very powerful in traumatic lesions, and the natives of Algeria are well acquainted with the fact". ${ }^{3}$ It is an old opinion that some waters have a remarkable power in cicatricial cases, and sulphur waters have enjoyed this reputation for centuries. It is believed that compresses of sulphur water are as efficacious as baths. I may here remind you that in France cold water dressings were strongly advocated in surgery by the great Ambroise Paré as long ago as 1553; and that they were much employed by the army surgeons in the Napoleonic Wars. No doubt this early aseptic practice was a great improvement upon the less cleanly methods then in vogue.

\section{Italy}

Italy is the chief inheritor of the Roman tradition, and for hundreds of years Italian physicians have been foremost in the advocacy of the rational employment of waters and climates. I need only refer to Savonarola, grandfather of the ill-fated prophet; to Baccius, of Venice, in the 16th century; to Giannini, of Milan, in the beginning of the 19th century; to Semmola, and Vinaj, and Maggiora, in our day. Professor Casciani, Lecturer on Medical Hydrology in the University of Rome, tells me that there are at present five military bath stations in Italy (Stabilimenti Balneari Militari) - namely, Acqui (160 beds), Recoara (60 beds), Castellamare-di-Stabia, on the Bay of Naples, and Salsomaggiore (30 beds), besides the hospital at Ischia, founded in 1875, with 120 beds. It is recorded that the baths of Bormio and Abano were used for soldiers in the sixth century.

I should add that in Italy, as in France, most of the great hospitals, civil as well as military, are equipped with appliances for hydrotherapy, that is, for baths at various temperatures, and for douches with and without massage, together with the ubiquitous electric light bath, so that in general physiotherapy is available in those countries for hospital patients, including military cases, without recourse to the special treatment of the health resort. Consequently, many military patients in those countries obtain bath treatments during their stay in hospital.

A short reference to the procedure by which military cases are selected for treatment at the Italian health resorts may be not without interest. These establishments are open in the summer months, and the cure is divided into 20-day periods, or mute. Lists of the cases recommended for treatment are made out in April and "forwarded to the administrative medical officer of the (territorial) division, who prepares a consolidated return, with remarks as to whether the case is suitable or not for undergoing a muta in the bathing establishment concerned. This goes to the War Office, and there a general roster of mute is prepared and issued to the army corps commanders for necessary action". 4 As regards the cost of treatment, there is a scale of payments, ranging from one penny per day for privates to eight shillings for general officers. It should be added that both officers and men may be sent to any of the sea-bathing resorts (bagni marini) for similar 20-day periods of cure, under local divisional arrangements.

\section{Austria-Germany}

In Germany, in addition to the convalescent homes there are institutions (Militär-Kuranstalten) for special after-treatment. These are 17 in number, and are distributed among various health resorts and wateringplaces in Germany. Among them may be mentioned the Wilhelm-Heilanstalt, which was established at Wiesbaden for wounded and sick officers and men after the wars of 1864 and 1866 . Wiesbaden, as we know, has a warm salt water, but the establishment is also fitted for simple hydrotherapeutic and medicomechanical treatment. At Landeck there is a similarly equipped Militär-Kurhaus, founded after the Danish campaign in 1864. Teplitz-Schönau in Bohemia is par excellence the "soldiers' spa" for Austria-Germany. The Militär-Bade Institut was founded by Friedrich Wilhelm III for the Prussian Army in 1825, with accommodation for three officers and 56 men. There are also separate establishments for the soldiers of Austria and of Saxony. The fame of these weakly mineralised thermal waters for wounds and injuries dates, like that of Eaux-Bonnes, from the experience after a single battle, the great Battle of Leipzig in 1813, after which large numbers of the wounded were brought to Teplitz for treatment. I should also mention the military bath hospital at Nauheim (43 beds); and there are other establishments at Driburg (Westphalia), Norderney, Suderode, Salzburg, and elsewhere.

Austria-Hungary has military hospitals (MilitärHeilanstalten in Kurorten) at most of the medicinal spas. According to Surgeon-General Macpherson, ${ }^{4}$ to whose writings I am indebted for these notes, they are 12 in number - namely, two at Baden, near Vienna, and one at each of the following places: Carlsbad, Teplitz- 
Schönau (already referred to), Hercules-Fürdo, HofGastein, Pöstyen, Trencsin-Teplitz, Budapest, Topusco, Lipik, and Töplitz. There is also for the Landwehr an establishment at Esiz.

\section{Russia}

In Russia, according to the same authority, there are 23 army medical stations (sanitarniya stantsii) devoted to the treatment of sufferers from chronic disease and for special treatments at health resorts.

\section{United States of America}

The Surgeon-General at Washington informs me that the United States Government maintains an Army and Navy General Hospital at Hot Springs, Arkansas, where suitable military cases obtain the natural baths and medical care at a nominal cost. These springs were reserved many years since by Act of Congress for the use of the State. This institution is at present the only one of its kind in America. The Commandant is good enough to tell me that it is complete in its hydrotherapeutic appliances, provision being made for all forms of baths, as well as for massage and temperature therapy. I am given to understand that all the larger general hospitals for the Army and Navy in the United States are equipped with a system of hydrotherapy.

\section{Japan}

I am told that in Japan wounded soldiers have been sent to the warm salt springs of Yamanaka and Atami, and for rheumatism to the hot sand baths of Верри.

\section{British Empire}

The foregoing is a brief account of the Military Bath Hospitals in other countries. That ours is a peace-loving land is perhaps the reason why there is no such establishment in connexion with any of the British waters, either in the three kingdoms or at the other hot springs of the Empire-whether in India, New Zealand, or elsewhere. Some of the British health resorts are well adapted for this purpose, and many years ago our Honorary President, Sir Hermann Weber, proposed the establishment of such a hospital at Bath. It is true that in most of the countries we have mentioned the thermal and other springs are the property of the State and not only the springs but even the great hospitals are State property. A government, like an individual, may well be more ready to utilise and develop its own resources than to perform the same service for private individuals, and medical opinion and authority are perhaps more readily focused upon therapeutic resources that are supported or recognised by the State. Those conditions for one reason or another have not hitherto existed in our country.

\section{Conditions amenable to bath treatment}

We may, in conclusion, briefly refer to some of the varieties of chronic disease, both surgical and medical, that are likely to be met with in soldiers and sailors leaving our military hospitals, and which we believe to be, in the majority of cases, amenable to bath treatment.

For an account of the known reactions of the body in various conditions of disorder and disease to medical baths, reference must be made to works upon hydrology. It must suffice to say here that these reactions have been recognised and defined with some precision, and that many of them follow with almost mathematical accuracy the slightest variation in the temperature, duration, or other characters of the bath. They can be invoked for the whole body or limited to particular parts. They can be varied and alternated at will, and made cumulative and more or less permanent by repetition. Like a ship's helm, these reactions respond to every movement of the steersman's hand. It will be conceded that bath treatments have therefore a potential both for good or evil, and that they require skill, not only in their choice, but in their administration.

\section{Surgical cases}

With reference to surgical cases, I may quote the summary in the French Cliniques hydrologiques. ${ }^{5}$ In simple fracture it is held that consolidation of the bone and restoration of the limb may be accelerated by several months by the use of baths. In compound fractures, and where osteitis and necrosis have occurred, certain baths, particularly some thermal and sulphur waters, seem to have the power, by modifying the nutrition of the part, to alter the suppurating surface and promote absorption of exudation and the discharge of sequestrce. In the case of fractures in the proximity of joints - for example, the knee-with stiffness following immobilisation, natural thermal baths at a temperature between $95^{\circ}$ and $105^{\circ} \mathrm{F}$ bring about decongestion of the tissues, and the re-absorption of peri-articular exudations, and at the same time counteract muscular atrophy and tendinous and articular stiffness. We may note here a familiar observation, that the movement of stiff and painful limbs, otherwise almost impossible, may often 
be performed with comparative ease in deep, hot baths. Long-continued baths at a somewhat lower temperature are employed not only for their general sedative effect, but to reduce oedema, relieve pain, and restore the local circulation.

It is a golden rule in hydrology that every kind of thermal bath is contra-indicated, not only in the presence of cardiac weakness, but also in febrile cases, and in acute or subacute or inflammatory conditions of all kinds; and that these baths, of which the heat is superior to that of the body, are applicable only in chronic disease, where the tissue reactions are defective and sluggish or perverted. It may often be observed in the history of a somewhat protracted case that there comes a moment when acute conditions have subsided and when a stimulating or thermal bath treatment is indicated, although previously inapplicable. Such stimulating measures would be injurious in the early stages of serious sprains, in peri-articular contusion, or in a traumatic arthritis or synovitis, in which it is above all necessary to allow the acute reactions to subside. But two or three months after the accident, should the pain and swelling persist, and muscular atrophy set in, salt or sulphur or thermal baths, according to individual conditions, together with massage, movements, and douches, have their proper and invaluable place.

The degree of heat to be employed in surgical cases needs careful consideration. We know that continued bathing at a moderate or sub-thermal temperature is by itself favourable to asepsis and to the cicatrisation of wounds. But higher or thermal temperatures may often be injurious, for example where, to quote again the French Cliniques, an unhealed cicatrix leads to an intermuscular sinus. On the other hand, these thermal temperatures, with or without douches and mechanical treatment, are helpful after many injuries - particularly for muscular and tendinous contractions; for nerve lesions, if the nerve is not divided or has been reunited, and where motor, sensory, and trophic symptoms have resulted from contusion or concussion of nerves in dislocation of a joint or splintering of bone; and lastly for removing articular adhesions, if not of too long standing. The same authorities emphasise the importance, in surgical cases, of choosing not only appropriate local treatment, but a bath station which is well adapted to the general condition of the patient's health.

\section{Rheumatism}

Rheumatic affections bulk largely in the health statistics of armies in times of peace, and the diagnosis "rheumatism" is quite as commonly used for those who are invalided in war. The conditions so designated are of course various, but sometimes appear to be analogous to what has been described as "fatigue fever," met with after extreme and long-continued physical exertion, as in forced marches, especially when the men are not fully trained. An excessive muscular metabolism causes in this condition an accumulation of waste products within the muscles, and a slight, general septic intoxication, the symptoms being exhaustion and stiffness and acute pain on movement. If the muscular work is too greatly prolonged, what has been called "organic exhaustion" ensues, perhaps with cerebral disturbance. ${ }^{6}$

In slighter cases immediate relief is obtained by stimulating the circulation in the muscles, and so sweeping away the waste products. A good example of this rapid cure of abnormal fatigue is the regulation hot bath after a day's hard deer-stalking in Scotland. We are told that at the Front hot baths are now greatly appreciated by men fatigued from duty. Even when the case is serious and of many weeks' duration, the judicious use of hyperthermal baths sometimes gives surprising relief.

Professor Russell, of Edinburgh, has recently given me a verbal account of some soldiers admitted under his care into the Royal Infirmary from the fighting line in France. Those men had been in the retreat from Mons and in the advance to the Aisne, and had been invalided on account of "rheumatism"; one of the men, who was in the Royal Field Artillery, was so ill before he left the Front that he had to be helped on to his horse, and when admitted to the infirmary seemed to have little power in his legs. All the men were very greatly and promptly relieved by a hot bath; the effect on the artilleryman was marked and immediate. The treatment in all the cases was curative. The bath was taken as hot as the patient could bear it, and some ammonia was added to the water.

Painful synovitis in a single joint, especially the knee, appears to be common in those who have occupied cramped positions in the trenches. In others there are deposits and thickenings in the connective tissues, more or less generalised, to which the names "fibrositis" and "neuritis" are variously applied. All experienced spa physicians will agree that such cases, when the acute phase has passed away, furnish a large proportion of successes in their practice.

\section{Nervous disorders}

Finally, with reference to nervous disorders, to the prevalence of which among sufferers from the war there is too much evidence, we have a sure basis for the use of baths. It has been proved that treatments operating upon the surface of the body have a powerful influence not only upon the circulatory but 
upon the nervous system. Moreover, according to the procedure employed, it is within our power to obtain widely different, and indeed entirely opposite, results. For example, with a proper choice of temperature, one may stimulate and increase, locally or generally, a depressed nervous action. At another range of temperature one can, with equal readiness, mitigate and diminish an excessive action, and that is as regards temperature alone. It is not too much to say that functional disturbance in either direction is amenable to surface treatment.

It follows that in many nervous disorders stimulant or sedative baths, skilfully adjusted to the case in hand, can be suitably employed. Where a stimulant effect is desired, hot air and other thermal baths and douches are to be preferred; but where, as is now too often the case, a more profound exhaustion is shown by irritability, depression and insomnia, we can recommend the sedative type of bath, given at a lower range of temperature and often continued for a considerable time.

In chronic nervous diseases and disorders but little distinction can be drawn between military and civil cases. I will only add that the treatment of these affections forms an important chapter in hydrological medicine.

Taken together, the foregoing indications, medical and surgical, appear to my own mind to point to the conclusion that baths of one kind or another have a useful place in the treatment of military cases. One word as to locality. The treatment must surely be first of all in the hospital, if and when such baths are to be found; second, in the town, where adequate baths and also means of transport are available; and, third, in the last stage, at the health resort.

During the coming year many men will leave our hospitals free from acute trouble, but suffering from its results. Not a few will exhibit, in addition to their local injuries, the effects of physical and mental shock. They cannot be returned to their homes, or even to convalescent homes, without further relief. They will need not only patient and prolonged care, but the knowledge that something is being done for them. The appropriate remedies, both physical and psychical, belong especially to the health resorts, and it is the raison d'etre of these places, when the acute illness has passed, to apply an after-treatment to the problems of incipient and chronic disease.

\section{References}

1. Spender. "The Bath Thermal Waters," 1882.

2. Weber. "Climatotherapy and Balneotherapy." 1907.

3. Hanriot. "Les Eaux minérales de l'Algérie," 1911.

4. Macpherson. "Handbook on the Medical Services of Foreign Armies.".

5. "Cliniques hydrologiques ("Bibliothèque de Thérapeutique clinique"), 1909.

6. Mosso, A. "Fatigue," 1904.

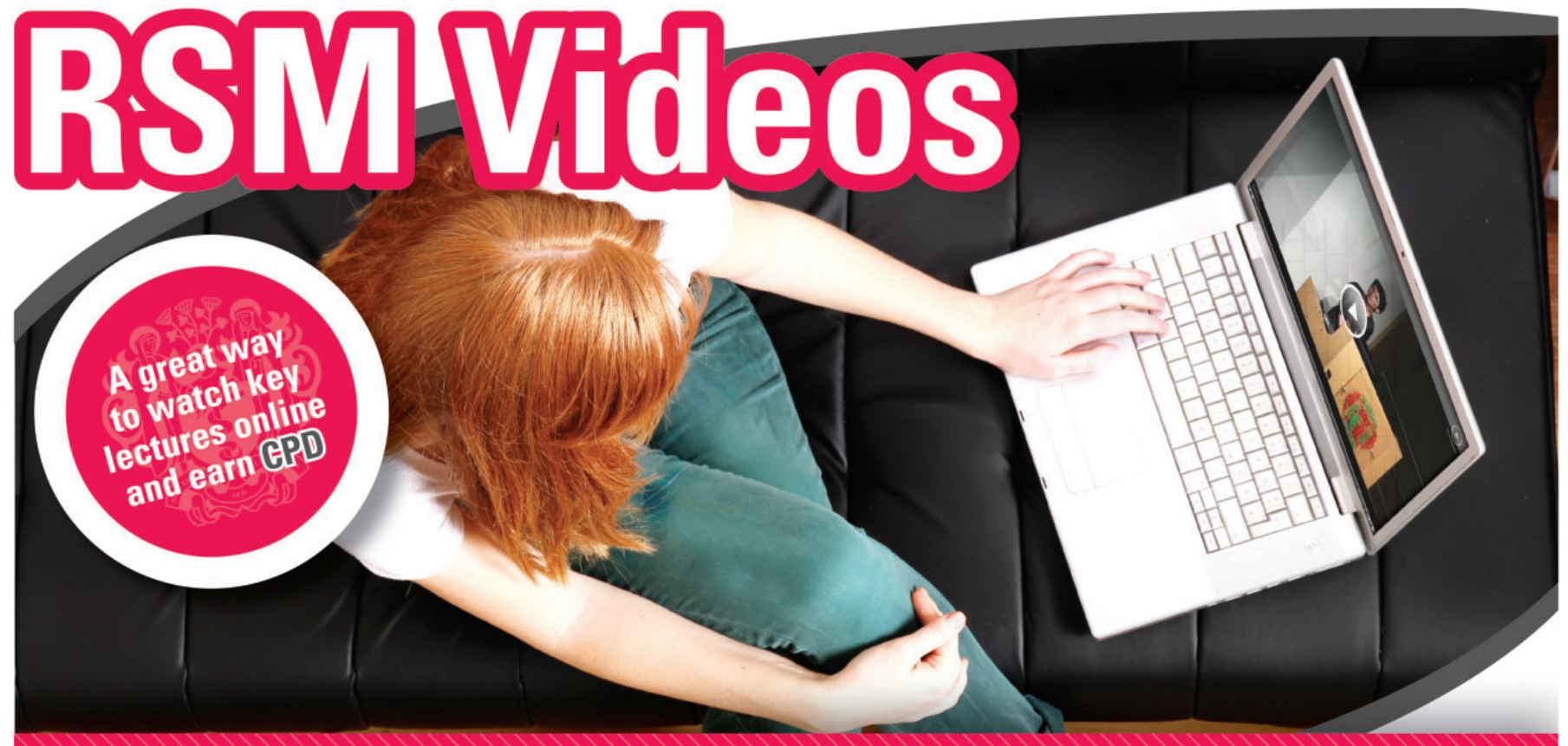

With over 300 lectures covering a wide range of specialties, RSM Members can benefit from RSM Videos and:

- Watch all lectures for free

- Earn CPD credits for just $f 12$

- Get 50\% off annual CPD subscription, paying only £95 per annum for unlimited CPD access

- New lectures added each week 